\title{
FORMULATION AND EVALUATION OF ORAL FAST DISINTEGRATING TABLET OF IBUPROFEN USING TWO SUPER DISINTEGRANTS
}

\author{
HRISHAV DAS PURKAYASTHA ${ }^{1}$, BIPUL NATH²
}

${ }^{1}$ Girijananda Chowdhury Institute of Pharmaceutical Science, Azara, Hatkhowapara, Guwahati-17, ${ }^{2}$ Depertment of Pharmaceutical Science, Girijananda Chowdhury Institute of Pharmaceutical Science, Azara, Hatkhowapara, Guwahati-17

Email: hforhrishav123@gmail.com

Received: 27 Jan 2017, Revised and Accepted: 20 Apr 2017

\begin{abstract}
Objective: The aim of the present investigation was to design and evaluate orally disintegrating tablet (ODT) of Ibuprofen, a NSAID drug used for the treatment of arthritis with a view to improve its oral bioavailability. The focus of the current study was to develop ODT of Ibuprofen using super disintegrants for ease of administration and its physicochemical characterization.
\end{abstract}

Methods: Tablets were made from blends by direct compression method. All the ingredients were passed through mesh no. 80. All the ingredients were co-ground in a pestle motor. The resulting blend was lubricated with magnesium stearate and compressed into tablets using the Cadmach single punch (round shaped, $8 \mathrm{~mm}$ thick) machine.

Results: Physicals parameters of the prepared tablets like Hardness, Weight variation, Friability, thickness, drug content etc. found within the limits. The disintegration time of prepared ODTs was in the range of 45 to 55 seconds. In vitro dispersion time was found to be 22 to 52 seconds which may be attributed to faster uptake of water due to the porous structure formed by super disintegrants. Short disintegration and faster release of ibuprofen were observed with Cross carmellose sodium as compared to sodium starch glycollate.

Conclusion: It is concluded that F3 offered the relatively rapid release of Ibuprofen when compared with other formulations. The increase in the concentrations of super disintegrants may lead to increase in the drug release. The formulation prepared with cross carmellose sodium was offered the relatively rapid release of Ibuprofen when compared with other concentrations of both the super disintegrant.

Keywords: Ibuprofen, Arthritis, Oral Bioavailability, Orally disintegrating tablet, NSAIDs

(C) 2017 The Authors. Published by Innovare Academic Sciences Pvt Ltd. This is an open access article under the CC BY license (http://creativecommons.org/licenses/by/4.0/) DOI: http://dx.doi.org/10.22159/ijcpr.2017v9i4.20966

\section{INTRODUCTION}

Fast disintegrating tablets are solid dosage form containing medical substances which disintegrate rapidly, usually within few seconds when placed upon tongue requiring no additional water to facilate swallowing. Direct compression is one of the techniques requires the incorporation of super disintegrants into the formulation the use or highly. The basic approach used in the development of FDT was the use of super disintegrants like cross-linked Croscarmellose Sodium, Polyvinyl Pyrrolidone, Microcrystalline Cellulose, Crospovidone etc. which provide instantaneous disintegration of the tablet after placed on the tongue, thereby releasing the drug in saliva [1-3].

Ibuprofen is a medication in the nonsteroidal anti-inflammatory drug (NSAID) class that is used for treating pain, fever, and inflammation. This includes painful menstrual periods, migraines, and rheumatoid arthritis. About $60 \%$ of people improve with any given NSAID, and it is recommended that if one does not work then another should be tried. It may also be used to close a patent ductusarteriosus in a premature baby. It can be used by mouth or intravenously. It typically begins working within an hour. The rate of bioavailability of Ibuprofen is highly variable due to their low aqueous solubility. The major problem with the drug is its very low solubility in biological fluids and its short biological half-life of $2 \mathrm{~h}$. Common side effects include heartburn and a rash. Compared to other NSAIDs it may have fewer side effects such as gastrointestinal bleeding. It increases the risk of heart failure, kidney failure, and liver failure. At low doses, it does not appear to increase the risk of myocardial infarction; however, at higher doses, it may. Ibuprofen can also result in worsened asthma. While it is unclear if it is safe in early pregnancy, it appears to be harmful in later pregnancy and therefore is not recommended $[1,3,4]$.

Like other NSAIDs, it works by inhibiting the cyclooxygenase (COX) enzymes, which convert arachidonic acid to prostaglandin $\mathrm{H} 2$
(PGH2). PGH2, in turn, is converted by other enzymes to several other prostaglandins (which are mediators of pain, inflammation, and fever) and to thromboxane A2 (which stimulates platelet aggregation, leading to the formation of blood clots). Ibuprofen might be a weaker anti-inflammatory than other NSAIDs. In recent years, fast dissolving tablets have been developed to overcome problems related to swallowing difficulties. Solid dosage forms that can be disintegrated, dissolved, or suspended by saliva in the mouth resulting in easy swallowing can provide significant benefits to the paediatric and geriatric population, as well as other patients who prefer the convenience of easily swallowable dosage forms. In the present study, an attempt has been made to formulate it as fast dissolving tablets to increase its oral bioavailability $[1,4,6]$.

\section{MATERIALS AND METHODS}

\section{Materials}

Ibuprofen purchased from Ciron Drugs, Mumbai, Sodium starch glycolate, crospovidone, Croscarmellose sodium, Mannitol, Microcrystalline cellulose, talc and magnesium stearate were purchased from Prachin Chemicals, Gujrat, India. All other materials used were of analytical grade.

\section{Methods}

The critical parameters to formulate a fast dissolving tablet are the choice of super disintegrant and optimisation of the concentration of super disintegrant. The main criteria for fast dissolving tablets is to disintegrate or dissolve rapidly in the oral cavity in 15-60 seconds, without the need of water and should have pleasant mouth feel. Fast dissolving tablets of Ibuprofen were prepared using direct compression method incorporating super disintegrants microcrystalline cellulose, Croscarmellose Sodium. The Ibuprofen equivalent to $100 \mathrm{mg}$, Mannitol and Microcrystalline Cellulose were mixed thoroughly in glass mortar using 
a pestle. Super-disintegrants were incorporated in the powder mixture according to each formulation in the tablets and finally Aspartame, Talc and Magnesium stearate was added. The whole mixture was passed through Sieve No. 80 twice. Tablets were prepared using Cadmach single punch (round shaped, $8 \mathrm{~mm}$ thick) machine [1-5].

Table 1: Formulation of ibuprofen fast disintegrating tablets

\begin{tabular}{|c|c|c|c|c|c|c|c|}
\hline \multirow[t]{2}{*}{ S. No. } & \multirow[t]{2}{*}{ Ingredients } & \multicolumn{6}{|c|}{ Formulation code } \\
\hline & & F1 & F2 & F3 & F4 & F5 & F6 \\
\hline 1 & Ibuprofen & 100 & 100 & 100 & 100 & 100 & 100 \\
\hline 2 & Sodium starch Glycollate & - & 2 & 4 & 6 & 8 & 10 \\
\hline 3 & Cross carmellose sodium & - & 2 & 4 & 6 & 8 & 10 \\
\hline 4 & Mannitol & 52 & 48 & 44 & 40 & 36 & 32 \\
\hline 5 & MCC & 40 & 40 & 40 & 40 & 40 & 40 \\
\hline 6 & Talc & 3 & 3 & 3 & 3 & 3 & 3 \\
\hline 7 & Magnesium stearate & 3 & 3 & 3 & 3 & 3 & 3 \\
\hline \multirow[t]{2}{*}{8} & Aspartame & 2 & 2 & 2 & 2 & 2 & 2 \\
\hline & Total Weight & 200 & 200 & 200 & 200 & 200 & 200 \\
\hline
\end{tabular}

\section{Evaluation}

\section{Pre-compression parameters}

\section{Angle of repose}

The angle of repose of a granular material is the steepest angle of descent or dip relative to the horizontal plane to which a material can be piled without slumping. At this angle, the material on the slope face is on the verge of sliding. Angle of repose was determined using fixed funnel method. The blend was poured through a funnel that can be raised vertically until a maximum cone height $(\mathrm{h})$ was obtained. The radius of the heap ( $\mathrm{r}$ ) was measured and angle of repose was calculated using formula $[1,6,7]$.

$$
\theta=\tan -1(\mathrm{~h} / r)
$$

Where $\theta$ is the angle of repose,

$\mathrm{h}$ is the height of pile and $\mathrm{r}$ is the radius of the base pile.

\section{Bulk density}

Bulk density is a property of powders, granules, and other "divided" solids, especially used in reference to mineral components (soil, gravel), chemical substances, (pharmaceutical) ingredients, foodstuff, or any other masses of corpuscular or particulate matter. It is defined as the weight of many particles of the material divided by the total volume they occupy. The total volume includes particle volume, inter-particle void volume, and internal pore volume. It is the ratio of the bulk mass of powder to the bulk volume. It is denoted by $\rho b$. Bulk density is used to find out homogeneity $[1,6,8]$.

$$
\text { Bulk density }(\rho b)=M / V_{b}
$$

Where $\mathrm{M}$ is the mass of the sample,

\section{$\mathrm{V}_{\mathrm{b}}$ bulk volume.}

\section{Tapped density}

It is the ratio of the weight of powder to the minimum volume occupied in measuring cylinder. Tapped density is determined by placing a graduated cylinder containing known mass of drug or formulation on a mechanical tapper apparatus which is operated at fixed no. of taps (50) until the powder bed reached a minimum volume $[1,9,10]$.

Tapped density $(\rho t)=$ weight of powder blend/Minimum volume occupied by cylinder

\section{Carr's compressibility index}

The simplex way of measurement of the free flow of powder is compressibility, an indication of the ease with which a material can be induced to flow is given by compressibility index of the granules was determined by Carr's compressibility index (C) which is calculated by using the following formula $[1,9,10]$.

$$
C=[(\rho t-\rho b / \rho t)] \times 100
$$

\section{Hausner ratio}

Hausner ratio is an indirect index of ease of powder flow. It is calculated by the following formula $[1,9,11]$.

\section{Hausner ratio $=$ Tappeddensity $/$ Bulkdensity}

Lower hausner ratio $(<1.25)$ indicate better flow properties than higher ones (>1.25).

\section{Post compression parameters}

All the batches of tablets were evaluated for various parameters like weight variation, friability, hardness, drug content, disintegration and dissolution and results reported in table 3 .

\section{Uniformity of weight}

This test is performed to maintain the uniformity of weight of each tablet which should be in the prescribed range, this is done by sampling and weighing 20 tablets at random and average weight is calculated. Not more than two of the individual weights deviate from the average weight by more than the percentage shown in the table 3 and none deviate by more than twice the percentage The mean and standard deviation were determined $[1,9,12]$.

\section{Thickness}

The thickness and diameter of the tablets was determined using a Micrometre screw gauge. Five tablets from each type of formulation were used and average values were calculated. It is expressed in $\mathrm{mm}$ $[1,9,13]$.

\section{Hardness test}

The hardness of the tablet was determined using Monsanto Hardness Tester [1, 9].

\section{Friability test}

Six tablets from each batch were examined for friability using Roche Fribilator and the equipment was run for 4 min at 25 revolutions per minute. The tablets were taken out, dedusted and reweighted and \% friability was calculated $[1,9,13]$.

$$
\begin{gathered}
\text { Percent friability }=(\text { Initial weight }- \text { Final weight }) / \text { Initial weight } \\
\times 100
\end{gathered}
$$

\section{Water absorption ratio}

A piece of tissue paper folded twice was kept in a Petri dish (internal diameter $5.5 \mathrm{~cm}$ ) containing $6 \mathrm{ml}$ of purified water. The tablet was placed on the tissue paper and allowed to wet completely. The wetted tablet was removed and reweighted. Water absorption ratio, $\mathrm{R}$ was determined according to the following equation $[1-3,9]$.

$$
R=(\mathrm{wa}-\mathrm{wb}) / \mathrm{wb} \times 100
$$

Where $\mathrm{Wb}$ and $\mathrm{Wa}$ are the weight before and after water absorption, respectively. 


\section{Wetting time}

A piece of tissue paper $(12 \mathrm{cmX} 10 \mathrm{~cm})$ folded twice was placed in a small Petri dish (ID $=9 \mathrm{~cm}$ ) containing $6 \mathrm{ml} \mathrm{pH} 6.8$ phosphate buffer, A tablet was placed on the paper and the time taken for complete wetting was noted. Three tablets from each formulation were randomly selected and the average wetting time was noted $[1,9]$.

\section{Content uniformity}

Twenty tablets were powdered, and powder equivalent to $100 \mathrm{mg}$ of Ibuprofen was accurately weighed and transferred into a $100 \mathrm{ml}$ volumetric flask. Initially, $5 \mathrm{ml}$ methanol was added and shaken for $10 \mathrm{~min}$. Then, the volume was made up to $100 \mathrm{ml}$ with 6.8 phosphate buffer. The solution was filtered, diluted suitably and analyzed spectrophotometrically at $221 \mathrm{~nm}[1,9]$.

\section{In vitro dispersion time}

Tablet was added to $10 \mathrm{ml}$ of phosphate buffer solution $\mathrm{pH} 6.8 \mathrm{pH}$ of saliva) at $37 \pm 0.5^{\circ} \mathrm{C}$. The time required for complete dispersion of tablet was measured $[1,10]$.

\section{Disintegration test}

The disintegration time for all formulations was carried out using tablet disintegration test apparatus. Six tablets were placed individually in each tube of disintegration test apparatus. The water was maintained at a temperature of $37^{\circ} \pm 0.5^{\circ} \mathrm{C}$ and time taken for the entire tablet to disintegrate completely was noted $[9,12]$.

\section{In vitro dissolution studies}

In vitro dissolution studies are performed by using USP dissolution test apparatus using 6.8 phosphate buffer as dissolution medium. The paddles are allowed to rotate at speed of $100 \mathrm{rpm}$. The dissolution medium was maintained at a temperature of $37 \pm 0.5^{\circ} \mathrm{C}$ and samples are withdrawn at an interval of every $5 \mathrm{~min}$. The volume of the withdrawn samples is replaced by fresh dissolution medium in order to keep the volume of the dissolution medium as constant. The withdrawn samples were filtered and absorbance was measured at absorption maxima of $221 \mathrm{~nm}$ using UV-visible spectrophotometer $[5,9,12]$.

\section{RESULTS AND DISCUSSION}

Ibuprofen fast disintegrating tablets were prepared by direct compression method was carried out by using super disintegrants and other excipients as mentioned in formulation chart (table 1). A total number of six formulations were prepared by direct compression method. The pre-formulation studies such as bulk density, tapped density, the angle of repose, compressibility index and Hausner ratio were evaluated (table 2). All the pre-formulation The data obtained from physicochemical parameters such as hardness, friability, and weight variation, drug content, wetting time, disintegration time, dispersion time and in vitro drug dissolution are shown in table 3. Out of all formulations, F3 was found satisfactory.

Table 2: Pre-formulation properties for formulation blends

\begin{tabular}{|c|c|c|c|c|c|c|c|}
\hline \multirow[t]{2}{*}{ S. No. } & \multirow[t]{2}{*}{ Pre-compression parameter } & \multicolumn{6}{|c|}{ Formulation code } \\
\hline & & F1 & F2 & F3 & F4 & F5 & F6 \\
\hline 1 & Angle of repose $\left({ }^{\circ}\right)$ & 26.8 & 27.5 & 27.9 & 26.7 & 27.8 & 29.1 \\
\hline 2 & Bulk density $\left(\mathrm{gm} / \mathrm{cm}^{3}\right)$ & 0.43 & 0.42 & 0.44 & 0.48 & 0.42 & 0.41 \\
\hline 3 & Tapped density $\left(\mathrm{gm} / \mathrm{cm}^{3}\right)$ & 0.49 & 0.52 & 0.53 & 0.52 & 0.55 & 0.53 \\
\hline 4 & Carr's index & 12.54 & 14.21 & 13.54 & 15.1 & 14.8 & 13.8 \\
\hline 5 & Hausner's ratio & 1.15 & 1.19 & 1.18 & 1.17 & 1.14 & 1.12 \\
\hline
\end{tabular}

Table 3: Post-compression studies of tablet

\begin{tabular}{|c|c|c|c|c|c|c|c|}
\hline \multirow[t]{2}{*}{ S. No. } & \multirow[t]{2}{*}{ Post-compression parameter } & \multicolumn{6}{|c|}{ Formulation cade } \\
\hline & & F1 & F2 & F3 & F4 & F5 & F6 \\
\hline 1 & Hardness $\left(\mathrm{kg} / \mathrm{cm}^{2}\right)$ & 3.5 & 4 & 3.8 & 3.6 & 3.9 & 4 \\
\hline 2 & $\%$ Weight variation & 3 & 4 & 3.5 & 2.5 & 3.4 & 4.1 \\
\hline 3 & Friability (\%) & 0.5 & 0.4 & 0.6 & 0.2 & 0.4 & 0.3 \\
\hline 4 & Average weight (mg) & 199.5 & 202.1 & 200.4 & 201.8 & 200.9 & 198.9 \\
\hline 5 & Drug content $(\%)$ & 99.5 & 98.7 & 100.5 & 101.2 & 99.9 & 98.8 \\
\hline 6 & Disintegrating time (sec) & 85 & 80 & 70 & 65 & 55 & 44 \\
\hline 7 & Water absorption Ratio & 47 & 61 & 75 & 84 & 91 & 99 \\
\hline 8 & Wetting time (sec) & 51 & 58 & 45 & 40 & 35 & 29 \\
\hline 9 & In vitro dispersion time (min) & 8.2 & 6.5 & 4.1 & 3.5 & 2.4 & 2.0 \\
\hline
\end{tabular}

Table 4: Dissolution profile of formulation

\begin{tabular}{|c|c|c|c|c|c|c|c|}
\hline \multirow[t]{2}{*}{ S. No. } & \multirow[t]{2}{*}{ Time (min) } & \multicolumn{6}{|c|}{ Formulation code (\% drug release) } \\
\hline & & F1 & F2 & F3 & F4 & F5 & F6 \\
\hline 1 & 5 & 14.36 & 14.25 & 16.21 & 15.27 & 13.52 & 12.21 \\
\hline 2 & 10 & 25.26 & 25.19 & 29.54 & 26.15 & 26.87 & 23.40 \\
\hline 3 & 15 & 39.0 & 38.24 & 45.85 & 41.65 & 40.27 & 37.81 \\
\hline 4 & 20 & 53.01 & 53.85 & 55.21 & 45.21 & 46.89 & 42.65 \\
\hline 5 & 25 & 66.24 & 65.17 & 62.74 & 63.87 & 61.29 & 55.39 \\
\hline 6 & 30 & 68.74 & 71.21 & 68.98 & 70.49 & 69.87 & 65.21 \\
\hline 7 & 35 & 70.21 & 72.15 & 73.80 & 74.85 & 73.41 & 70.90 \\
\hline 8 & 40 & 76.29 & 77.27 & 79.21 & 78.17 & 76.85 & 73.85 \\
\hline 9 & 45 & 81.36 & 83.15 & 86.87 & 85.69 & 83.21 & 77.39 \\
\hline 10 & 50 & 87.67 & 87.29 & 91.25 & 87.21 & 85.32 & 80.28 \\
\hline 11 & 55 & 91.28 & 90.73 & 94.24 & 92.48 & 89.91 & 85.41 \\
\hline 12 & 60 & 92.24 & 94.28 & 97.51 & 95.54 & 93.47 & 89.57 \\
\hline
\end{tabular}

\section{CONCLUSION}

It is therefore concluded that F3 offered the relatively rapid release of Ibuprofen when compared with other formulations Increase in the concentrations of super disintegrants may lead to increase in the drug release. The formulation prepared with cross carmellose sodium was offered the relatively rapid release of Ibuprofen when compared with other concentrations of both the super disintegrant. 


\section{CONFLICT OF INTERESTS}

Declare none

\section{REFERENCES}

1. Kishore VS, Kumar DG, Sudheer D, M Sandeep M. Design and development of fast dissolving tablets of ibuprofen. J Pharm Pharm Sci 2013;2:65-71.

2. Rane DR, Gulve HN, Patil VV, Thakare VM, Patil VR. Formulation and evaluation of fast dissolving tablet of albendazole. Int Curr Pharm J 2012;1:311-6.

3. Lakshmi AG, Patel R, Kumar DS. Formulation and evaluation of fast dissolving tablets of antiemetic drug metoclopramide. World J Pharm Pharm Sci 2014;3:2080-90.

4. Bandari S, Mittapalli RK, Gannu R, Rao YM. Oral dispersible tablets: an overview. Asian J Pharm 2008;1:2-11.

5. Van SEA, Lechat P, Remmerie BM, Ko G, Lasseter KC, Mannaert E. Pharmacokinetic comparison of fast-disintegrating and conventional tablet formulations of risperidone in healthy volunteers. Clin Ther 2003;25:1687-99.

6. Sastry SV, Nyshadham JR, Fix JA. Recent technological advances in oral drug delivery-a review. Pharm Sci Technol Today 2000;3:138-44.
7. Kumar JS, Meenakshi S, Vivek S. Development and in vitro evaluation of ibuprofen mouth dissolving tablets using solid dispersion technique. Chem Pharm Bulletin 2010;58:1037-42.

8. Battue SK, Repay MA, Maunder S, Rio MY. Formulation and evaluation of rapidly disintegrating tablet fenoverine tablets: effect of super disintegrants. Drug Dev Ind Pharm 2007;33:1225-32.

9. Indian Pharmacopoeia. The government of India, Ministry of Health and Family Welfare, Ghaziabad, New Delhi, The Indian Pharmacopoeia Commission Publisher; 2007.

10. Bradoo R, Shahani S, Poojary S, Deewan B, Sudarshan S. Fast dissolving drug delivery systems. JAMA India 2010;4:27-31.

11. Cook GC. Use of benzimidazole chemotherapy in human helminthiases: Indications and efficacy. Parasitol Today 1990;6:133-6.

12. Indurwade $\mathrm{NH}$, Rajyaguru $\mathrm{TH}, \mathrm{Nakhat} \mathrm{PD}$. Novel approach fast dissolving tablets. Indian Drugs 2002;39:405-9.

13. European Pharmacopoeia. Directorate for the Quality of Medicines of the Council of Europe (EDQM). 5th edition; 1988.

\section{How to cite this article}

- Hrishav Das Purkayastha, Bipul Nath. Formulation and evaluation of oral fast disintegrating tablet of ibuprofen using two super disintegrants. Int J Curr Pharm Res 2017;9(4):92-95. 